Professor i fransk litteratur

Københavns Universitet

FREDERIK TYGSTRUP

Professor i Litteraturvidenskab

Institut for Kunst- og Kulturvidenskab, Københavns Universitet.

\title{
FRA NORMATIV TIL HISTORISK TOPOS-FORSKNING
}

Topos-begrebet kommer, som mange andre litteraturvidenskabelige begreber, f.eks. stil, genre og figur, fra den klassiske retorik. Og som disse lider topos-begrebet også af at være ganske udbredt, samtidig med at dets betydning er nok så uklar. I den klassiske retorik var det almindeligt at skelne mellem på den ene side generelle topoi og på den anden side specifikke topoi, der var anvendelige og nyttige i særlige sammenhænge ${ }^{1}$. De førstnævnte topoi er skemaer for argumentation eller argumenttyper, f.eks. årsag-virkning, definition af genstande, lighed-forskel, mere overfor mindre, del overfor helhed, og så videre, som altså hjælper med at konstruere argumenter på grundlag af logisk sandsynlighed. De specifikke topoi er indholdsargumenter, som er nyttige i bestemte sammenhænge og taleregistre: I forsvaret af den kriminelle kan toposet "ulykkelig barndom" bruges til at appellere til særlige ideer om barmhjertighed, forståelse og retfærdighed. Denne retoriske forståelse af toposet som både logisk værktøj og heuristisk hukommelsesværktøj til at skabe overbevisende argumenter gjaldt i antikken for de tre talegenrer: retstalen, den politiske tale og lovtalen. Men hvilken relevans har denne forståelse af toposet for den litterære topologi?

1 Se f.eks. Amossy et al. 66 og Perelman 36. 
Selv om det ofte er blevet påpeget, at antikken ikke kendte til "litteratur" i den moderne forstand af ordet, skal fire forhold alligevel understreges. For det første at lovtalen, som jo roser eller kritiserer personer, og som gerne anvender overdrivelse og hypostasering, og som har skønheden som mål, godt kan tilnærmes, og er blevet det, "litteratur" i moderne forstand. For det andet befinder de forskellige topoi sig i den del af retorikken, som kaldes inventio. Hvis man, som allerede antydet, skal vare sig for anakronismer i denne sammenhæng, eftersom inventio blot betyder forhåndenværende topiske ressourcer, så er det ikke at udelukke, at talerens forhold til disse ressourcer kunne være af delvist kreativ art. I den forbindelse bemærker Olivier Reboul, at retorikken er "en kode der tjener en kreativitet" (Reboul 65), og at sidstnævnte for det tredje støttes af de mere litterære og æstetiske dele af retorikken (særligt dispositio og elocutio). For det fjerde bør det understreges, at de poetiske genrer, tragedien, komedien og eposet (og sågar prosaen fra og med Gorgias), også er tænkt ud fra den epideiktiske genres ide om lovprisning og dadel med udgangspunkt i topiske dyder og laster. Selv om retorikken og poetikken er forskellige i deres formål, deler de ikke desto mindre idealet om at konstruere en sandsynlig (og ikke en sand) argumentation via topiske, det vil sige kulturelt accepterede, forestillinger.

\section{CURTIUS OG BAKHTIN}

Den tyske romanist Ernst Robert Curtius var den første til at udvikle en egentlig litterær topologi. Det er særligt i Europäische Literatur und lateinisches Mittelalter fra 1948, at han udvikler sin toposteori. Denne er inspireret af A.J. Toynbees civilisationsteori, af Bergsons vitalisme og af C.G. Jungs dybdepsykologi, og Curtius optegner et imponerende tableau over den europæiske litteraturs kulturelle oprindelse og dynamik ud fra netop de historiske bevægelser mellem retoriske og poetiske topoi. Curtius viser, hvordan en række topoi fra den senantikke retorik overføres til den europæiske middelalderlitteratur. Med det romerske imperium undergår litteraturen en "retorisering" således, at den antikke litteratur arver en række retoriske fremstillingsmetoder, herunder dem, der angår retorikkens topoi. Men en modsat bevægelse finder ifølge Curtius også sted, eftersom det ikke er alle topoi, der kommer fra retorikken: Nogle af dem fødes med den 
antikke poesi for senere at glide over i retorikken. Lad os citere en i denne sammenhæng afgørende passage fra Curtius' hovedværk:

Den poetiske topik tilhører området for det naturskønne i videste forstand - det ideale landskab og dets typiske kendetegn. Men også ønskedrømme og drømte tider: elysium (med evigt forår uden meteorologiske uregelmæssigheder), det jordiske paradis, den gyldne tidsalder. Men også livets magter: kærlighed, venskab, forgængelighed. Alle disse forhold vedrører urforhold i tilværelsen og er derfor tidløse, nogle i højere grad, nogle i mindre grad. Blandt de sidste er venskabet og kærligheden. De afspejler forskellene mellem de sjælelige epoker, der følger efter hinanden. Historisk betinget er derimod for samtlige poetiske topois vedkommende den stil, som de udsiges i. Men der findes også topoi, som er fraværende gennem hele antikken frem til Augustus' århundrede. De dukker op i senantikken og findes derefter pludselig overalt. [...] De er interessante af flere grunde. For det første i litteraturbiologisk henseende: Vi kan i dem studere tilblivelsen af nye topoi og dermed udvide vores genetiske forståelse af litterære formelementer. Og for det andet er sådanne topoi udtryk for en forandret sjælelig tilstand, udtryk, der ikke kan opfattes på anden måde. Således kan vi uddybe vores forståelse af den vestlige sjæls historie, og vi berører hermed områder, som er blevet åbnet af C.G. Jungs psykologi. [...] Alt imens den antikke topik er del af en lærebygning, dvs. systematisk og normativ, forsøger vi her at berede grunden for en historisk topik. (Curtius, Europäische Literatur 92)

Lad os understrege to forhold i dette citat, som tilsammen angiver kompleksiteten i Curtius' tanke om topoi. Curtius forsøger, i modsætning til den normative klassiske topologi, at etablere en historisk topologi. Den historiske optik tillader, ifølge Curtius, at forstå i hvilket omfang topoi fra de to diskurser er dynamiske, og hvordan de nærer sig ved hinanden. I det øjeblik middelalderlitteraturen (ikke bare de klassiske genrer men også homiletikken, brevkunsten og hagiografien) overtager retorikkens topoi og bruger dem i en poetisk sammenhæng, konstituerer den også en historisering af den antikkens normative topologi. Endvidere er det det stilistiske blik, der tillader at identificere disse mutationer, som Curtius siger: De historisk varierende stiltræk er udtryk for, at den menneskelige ånd udvikler sig. Denne påstand forbinder ikke bare stilen med åndens hi- 
storicitet, men tildeler i samme gestus også de litterære topoi en kompleks, hvis da ikke tvetydig, rolle. På den ene side er disse topoi, sammen med alle de andre formelle træk, tegn på den europæiske ånds civilisatoriske udvikling, der starter efter det romerske imperium. Mange andre steder understreger Curtius i øvrigt, at topoi er at regne til det samme niveau, som andre formelle elementer tilhører (Curtius, Europäische Literatur f.eks. 162). Men disse topoi er på den anden side også universelle. De angår "tilværelsens fundamentale vilkår" og er således, som Curtius siger det, "tidløse". Den tyske original taler således i den forbindelse om "Urverhältnisse des Daseins". ${ }^{2}$ Men er disse topoi så universelle, eller er de historiske tegn på åndelig udvikling? Kommer de fra den menneskelige eksistens' grundvilkår eller er de historiske former? En ofte citeret topos-definition fra Curtius' hånd er faktisk afslørende for dette problem: "Topoi, det vil sige faste vendinger eller tanke- og udtryksskemaer" (Curtius, "Beiträge zur Topik" 1) Denne mangel på klarhed i Curtius' toposdefinition har naturligvis medført en række mere eller mindre velmente kritikker (Cf. Baeumer, "Vorwort" og Obermayer, "Zum Toposbegriff"). En måde at belyse og overskride denne definitionsproblematik på ville være at genlæse det lange første citat af Curtius og opholde sig ved en af hans formuleringer:

[...] livets magter: kærlighed, venskab, forgængelighed. Alle disse forhold vedrører urforhold i tilværelsen og er derfor tidløse, nogle i højere grad, nogle i mindre grad. Blandt de sidste er venskabet og kærligheden. De afspejler forskellene mellem de sjælelige epoker, der følger efter hinanden. Historisk betinget er derimod for samtlige poetiske topois vedkommende den stil, som de udsiges i. (Curtius, Europäische Literatur 92)

2 Henvisningen til Jungs arketyper skal faktisk tages seriøst hos Curtius. I behandlingen af toposet "den gamle dame og den unge pige" overraskes Curtius over at finde det i Balzacs fortælling Jésus-Christ en Flandres (1831); genkomsten af dette topos, som han har fundet varianter af i Hermas Hyrden og hos Claudius Aelianus og Boethius, får ham til at slutte, at "den eneste mulige forklaring på denne genkomst er, at dette topos har sine rødder i menneskesjælens dyb. Det tilhører det kollektivt ubevidstes ældste billeder" (Curtius, Europäische Literatur 123).

3 "Topoi, d. h. feste Clichées oder Denk- und Ausdrucksschemata" (Curtius, "Beiträge zur Topik" 1). 
Man kunne udlægge topos-ideen i denne passage som en slags intermediær form mellem tema og præsentationsstil. Et topos kan, afhængigt af konteksten, forstås som liggende tæt på de tidløse temaer eller på det formelle niveau i den gængse betydning af form, som kliché eller metafor, altså som stiltræk. Curtius siger det selv, topoi er "tankeskemaer" og "udtryksskemaer", og et givent topos kan være indplaceret på forskellige niveauer i dette topologiske rum. Det er netop denne definitionsfleksibilitet, som Curtius' formulering "nogle mere, nogle mindre" peger på. Således varierer deres status alt efter, om det er det poetiske topos "påkaldelsen af naturen", det retoriske topos "påtaget beskedenhed" eller det metaforiske topos "menneskets ånd er som et sejlskib". Hvert af disse topoi kan indplaceres i det topologiske rum mellem eksistentielle temaer og historiske former, hvor det første topos ligger tæt på temaet om menneskets veneration for naturen, det andet tæt på at være formelt retorisk topos i talen, mens det sidste topos er tematisk, for så vidt det indeholder en ide om menneskeåndens uvisse livsbetingelser, men også formelt i kraft af dets metaforiske form. På den måde er hvert topos, alt efter dets karakter, placeret på et særligt niveau mellem eksistentielt tema og historisk form, således at det etablerer medieringer mellem denne verdens temaer og deres stilhistoriske former. Det er derfor, Curtius kan fremkomme med den umiddelbart stormaskede definition af topoi som både klicheer, tankeskemaer og udtryksskemaer. Topologien er, for Curtius, en heuristisk videnskab, hvis mål det er at identificere hvert topos' formelle karakter, historiske stiltræk og tematiske mening.

Det gælder al genuin ny litteraturteori, som f.eks. Curtius', at den ikke får lov at stå uimodsagt, at den med en vis nødvendighed bliver kritiseret og udviklet. I Curtius' tilfælde har man ofte peget kritisk på den definitoriske vaghed i prægningen af toposbegrebet. Også civilisationstanken, som blev hentet hos Toynbee, har man peget fingre ad, mens arketypetænkningen fra Jung, som Curtius relativt ureflekteret støtter sig til, virker forældet.

Et interessant forhold ved Curtius' tænkning er imidlertid, at den jo eksplicit angår den europæiske middelalders litteratur. Hvornår denne middelalder slutter, er i øvrigt ikke helt klart, men man kan hæfte sig ved, at denne periode, også hvis man inkluderer 1400-tallet heri, trods alt fremstår relativt homogen, hvad angår brugen af litterære topoi. Dette kunne have noget at gøre med, at denne litteratur i højere grad end moderne litteratur 
var orienteret mod en psykologisk, moralsk, social og politisk idealitet. Man kunne gøre gældende, at et brud finder sted i europæisk litteratur på et tidspunkt i løbet af renæssancen i den bredeste betydning heraf, og at litteraturen herefter ikke blot orienterer sig efter en europæisk kulturel enhed med klassiske topoi eller traditionelle temaer (Cf. Curtius, "Historischen Topik"). Den nye litteratur, om det er Rabelais, Cervantes eller Defoe betyder ikke så meget i denne sammenhæng, forsøger og lykkes med at integrere nye steder, ikke fra retorikken, men konkrete og materielle steder fra den moderne verden. Hvis litteraturen ifølge Curtius var udspændt mellem fundamentale eksistentielle temaer på den ene side og på den anden side historiske stiltræk, som indikerede åndens historiske situation, så kunne man hævde, at en ny topologi ville skulle orientere sig mod den moderne virkeligheds nye konkrete og materielle steder og disses litterære repræsentation. Denne topologi ville skulle afkoble sig fra ideerne om åndens udvikling, fra arketyperne og fra de konventionelle retoriske topoi, for i stedet at undersøge, hvordan litteraturen bruger de narrative og symbolske muligheder, som en række nye steder synes at stille til rådighed.

Hermed får den vending, som Curtius foretager, fra en normativ til en historisk topik, en egentlig materiel artikulation. Hos Curtius er såvel den normative som den historiske topologi overvejende rettet mod toposets figurale aspekt. Til forskel herfra vil interessen for toposet som et faktisk sted være i stand til at medtænke de foranderlige historisk-materielle rammer, som forsyner den litterære topologi med dens stof, nemlig den menneskelige erfaringsverden. Denne konkret historiske forankring af topologien har fået en af sine mest prægnante formuleringer i en anden sammenhæng, nemlig i Mikhail Bakhtins lange essay om kronotopen. Der er næppe tvivl om, at begrebet om kronotopen er udformet i diskret polemik mod topos-forskningen, og at det krono-topiske - dvs. sammenhængen mellem menneskelig tid og oplevelsen af rum - er et forsøg på at udvide et for statisk begreb om det topiske. Menneskelivet udfolder sig altid, siger Bakhtin, i en konkret kombination af tid og rum: Rummet erfares i kraft af de konkrete, tidslige erfaringsforløb, som tager rummet i brug, og omvendt erfares tiden som en rumligt forankret proces. Det konkrete sted er altid allerede kronotopisk; det er Bakhtins ene pointe. Den anden er, at litteraturens billeder, dens "assimilation" af den historiske virkelighed 
(Bakhtin, "Forms of Time" 84), finder sted gennem en kunstnerisk komposition, der rekonstruerer erfaringens kronotopiske univers. Det afgørende i denne sammenhæng er imidlertid ikke først og fremmest Bakhtins originale sammenknytning af tid og rum, men derimod hans insisteren på sammenhængen mellem erfaringens kronotopier og de dynamiske steder, der fremstilles i litteraturen. Eller igen: at han inviterer til at orientere topologien mod konkrete - og prægnante - historiske steder, og dermed til at forstå toposet som en litterær, formel og stilistisk, sedimentering af et karakteristisk erfaringsrum. Med denne manøvre opnår Bakhtin to ting, som begge er af betydning for den historiske toposforskning. På den ene side giver han den en konkret historisk forankring ved at sætte fokus på sammenhængen mellem en historisk livsforms tid-rumlige organisering og de litterære billeder, der udspringer heraf. Og på den anden side viser han, hvordan disse billeder, disse formale "assimilationer", har deres eget videre liv i litteraturen: hvordan hele genrer kan udspringe af bestemte kronotopiske formationer, og hvordan det litterære materiale, der bliver til gennem assimilationen af bestemte tid-rumlige miljøer, viderebearbejdes, udvikles og forandres i den litteraturhistoriske proces. Eller med andre ord: hvordan det litterære topos har sin materielle forankring, og hvordan det lever videre i litteraturen som en del af en forms eller en genres udvikling.

Hvilke materielle topoi er det så de moderne forfattere opdager og privilegerer? Hvordan fremstilles de og til hvilke formål? Litteraturen fra det 17. og 18. århundrede anvender f.eks. flittigt steder som herberget, kroen, vejen, hestevognen, salonen, klosteret og kirken. Det 19. århundrede er mere orienteret mod borgerskabets steder som f.eks. restauranten, teatret, boulevarden, advokatkontoret, avisredaktionen og toget. Og det 20. århundrede udnytter hotellet, swimmingpoolen, flyet, lufthavnen, fabrikken, maskinen, men også det forvaltede samfunds institutioner (retssalen f.eks.), mens man også genfortolker naturens steder som blandingszoner mellem f.eks. autenticitet og kolonivold (deltaet, tågen og floden i f.eks. Conrad og Céline). Når Bakhtin taler om kronotopen som en "assimilation", så kan denne bestemmelse forstås som en invitation til at udvikle selve ideen om "sted" for efterfølgende at kunne analysere og forstå brugen af disse nye steder i tidlig moderne og moderne litteratur. Disse nye steder henter ikke deres mening og genkendelighed i en litterær tradition, ej heller i tematiske konstanter, 
og de adskiller sig ikke fra hinanden via stilhistoriske træk, som det ifølge Curtius var tilfældet med middelalderens litteratur. De nye litterære topoi er i højere grad udstyret med varierende mening som konsekvens af deres rolle i dagligdagen og i hverdagslivet. De nye opfindelser, institutioner og medier med tilhørende materialitet og fænomenologi, værdi og prestige, magt og konnotationer foranlediger nye litterære steder. Og selvom disse steder er nye, så fortjener de fint betegnelsen topoi, netop fordi de er fælles steder, delte og genkendelige, og dermed også udstyret med en art materiel doxa, som læserne uforvarende genkender og accepterer, som de så at sige lader sig overtale af. Således fremstår de nye topoi som en fælles forudsætning for meningsproduktion i et givet litterært værk, og hvis man accepterer denne præmis, kan man også tage Curtius bemærkning, om at der til enhver litterær teori hører en topik, alvorligt. ${ }^{4}$

\section{REALSTED OG LITTERÆRT STED}

Den udfordring topologien i dag stiller os, består, i første omgang, i at forsøge at præge et toposbegreb, som også er i stand til at identificere genkommende litterære steder som fysiske og historiske realiteter. Man finder et godt eksempel på et sådant forsøg hos Erich Auerbach i artiklen "La Cour et la ville". Heri behandler Auerbach to konkrete steder, som i den franske 1600-talskultur konstituerer matricen for to offentlige rivaliserende rum, domineret henholdsvis af en adelskultur og af den nye borgerlige kultur. Auerbach tager udgangspunkt i Molières komedier for at vise, hvordan disse to offentlige rum iscenesættes, hvordan deres modsætning tager form og især, hvordan de vikles sammen i 1600-tallets litterære verden. Uden at ville gå i detaljer med Auerbachs tekst er det klart, at vi her møder både ligheder med og forskelle fra Curtius' topologi. På den ene side, og i modsætning til Curtius, er "la cour" og "la ville" oplagt materielt og historisk forankrede. På den anden side virker det lige så klart, at "la cour" og "la ville" for Auerbach rummer en betydning, der overskrider deres

4 "Til den litteraturvidenskabelige metode hører også en "topik ". Og det skal være en historisk topik, i modsætning til den ældre normative topik." (Curtius, "Historischen Topik" 138). 
geografiske realitet. Der er snarere tale om netop kronotopiske realiteter, som afstikker formatet for en serie erfaringer og kendsgerninger: Nemlig politiske relationer (sidestillingen af offentlige rum), magtmæssige relationer (konfrontationen af to måder at dominere det politiske liv på) og affektive relationer (adelens og borgerskabets psykologiske idealer). På det niveau fungerer "la cour" og "la ville" mere eller mindre som temaer i curtiusk forstand med den forskel, at de ikke er traditionelle antropologiske temaer, men temaer, der er produceret af historisk specifikke omstændigheder. Hertil kommer, at Auerbachs analyse af disse historiske temaer synes analog til Curtius' analyser, for så vidt førstnævnte ikke stopper ved temaernes blotte eksistens, men fortsætter til deres udkrystallisering i specifikke litterære former, hvilket i Curtius' tekst blev forstået som en udveksling mellem tema og stil, og hos Bakhtin var et spørgsmål om en stilistisk "assimilation". Auerbach interesserer sig også for, hvad der sker med de historiske temaer, når de underlægges litterær behandling, og for hvilket udtryk deres konfiguration får i f.eks. Molières komedier. Ifølge dette ræsonnement bidrager Auerbachs studie fuldgyldigt til den udvikling af topologien, som Curtius påbegyndte ved at forsøge at forankre diverse topoi materielt og historisk. Forskellen mellem de to tænkeres teorier kan forklares metodologisk: hvor Curtius forstår temaerne som fundamentale antropologiske problemer, hvis variationer afhænger af Åndens historiske specificitet, så understreger Auerbach temaernes historiske specificitet og konkretion $^{5}$. Anderledes formuleret er der tale om en forskel mellem en idealistisk og en historisk forståelse af litteraturens topoi, hvilket, som sagt, også har noget at gøre med, hvilket genstandsfelt de to litterater analyserer, nemlig generelle litteraturhistoriske udviklingslinjer hos Auerbach og middelalderens antropologiske litteraturtopik hos Curtius.

Med identificeringen af et kvalificeret forsøg på en historisering af topologien i Auerbachs studie af "La cour et la ville" synes to spørgsmål imidlertid at rejse sig. For det første spørgsmålet om, hvordan man begrebsliggør det reelle sted som udgangspunkt for den litterære topologi, og

5 Som Auerbach selv understreger i forordet til Vier Untersuchungen zur Geschichte der Französischen Bildung, består den indre linje i hans litteraturhistoriske arbejde i forsøget på at nå frem til en "historisk topologi" (Auerbach, Vier Untersuchungen 7). 
for det andet spørgsmålet om, hvilken rolle den litterære repræsentation og dennes forvaltning af det historiske sted spiller for vores forståelse af det litterære topos. Man finder faktisk implicitte svar på disse spørgsmål i Auerbachs tekst. Som vi netop bemærkede, henviste "La cour et la ville" ikke bare til reelle og historiske steder, eftersom de også besad typiske træk. Selvom man kan finde konkrete referencer herpå i f.eks. Molière, så implicerer Auerbachs optik en bredere vision, der går fra analysen af parterrets funktion i det 17. århundrede til de sociopoltiske konflikter mellem adel og borgerskab. Det afgørende punkt i denne sammenhæng er, at der eksisterer et specifikt forhold mellem det konkrete sted og dets typiske kvaliteter. Det konkrete sted skal nemlig ikke ses som et "billede" eller et "symbol", der indeholder en mere komplet forståelse af en historisk situation eller dynamik. Hvis det konkrete sted på én gang besidder en specifik reference og en mere generel typisk prægnans, så er det fordi stedet er karakteriseret ved nogle specifikke egenskaber, en bestemt "kronotopisk" erfaringsorganisering med Bakhtin.

Det er altså afgørende at forstå stedets egenart på plastisk vis og ifølge dets historiske natur. Et sted er ikke bare en geografisk eller topografisk lokalitet, men en kronotopisk realitet, der er indskrevet i en konkret menneskelig og historisk livsverden. Her kan den historiske topologi støtte sig til den nyere livsverdenssociologi. Som Henri Lefebvre har understreget det (Lefebvre, La Production), så indbefatter et historisk sted en konkret sammenvævning af materielle kendsgerninger, det vil sige et naturligt, bymæssigt eller arkitektonisk miljø; af symbolske kendsgerninger, det vil sige måder at tænke, handle og organisere en social kollektivitet; og endelig en imaginær dimension, der indeholder former og modi for erfaring af den kropslige og mentale realitet. Identificeringen af et historisk prægnant sted indebærer således en koordinering af en række komplekse interaktioner mellem konkrete miljøer, politiske magtforhold, sociale adfærdsformer, historiske tænkemåder og de menneskelige erfaringer, som her rammesættes. Det er denne det menneskelige rums relationelle realitet, som karakteriserer det historisk prægnante sted og forlener det med en typisk karakter. Det er en sådan kompleks realitet Auerbach overbevisende udpeger, når han identificerer "la cour et la ville" som en central struktur, der samler en række væsentlige problemstillinger i det 17. århundredes Frankrig. 
Sådanne socialt og kulturelt prægnante steder er naturligvis underlagt radikale historiske variationer. Sidestillingen af hof og by indeholder en hel række afgørende problemstillinger i det 17. århundredes Frankrig, mens tysk kultur i det 19. århundrede eller amerikansk kultur i det 20. århundrede ville favorisere helt andre steder og andre problemstillinger. Identificeringen af sådanne steder, af forskellige rumlige konfigurationer og af de helt forskellige historiske problematikker som førstnævnte måtte indeholde, er en udfordring for kultur- og historievidenskaben. Men litteraturvidenskaben spiller en særlig rolle i denne sammenhæng, eftersom litteraturen besidder en privilegeret perception af disse historiske rumkonfigurationer. Den moderne litteraturs realistiske stil forudsætter en særlig interesse for repræsentationen af det menneskelige liv i dets historiske konkretion med de materielle rammer, diskursive former og erfaringsmodi, som konstituerer dette liv. Således er litteraturen en værdifuld kilde til forståelse af det basale historiske realitetsniveau, som den særligt prægnante stedskonfiguration danner. Men det betyder ikke omvendt, at man kan reducere litteraturen til en blot repræsenterende aktivitet, der udpeger disse steder og de menneskelige aktiviteter og erfaringsformer, der artikulerer dem som forhandlingsrum for centrale historiske problematikker. Litteraturen er selv, som Curtius allerede bemærkede det, en historisk praksis som former og på særlig vis artikulerer de problematikker, som den behandler. Analysen af den litterære repræsentation af reelle steder bliver dermed også en analyse af repræsentationsteknikker, altså af hvordan stilen udfolder og artikulerer disse steder og deres historiske problematikker, af hvordan den litterære repræsentation gør disse steder sanseliget nærværende og deres problematikker begribelige i den menneskelige livsverdens perspektiv. Anderledes formuleret handler det her om både den repræsenterede genstand og om repræsentationen. Mere præcist formuleret består den udfordring, topologien stiller litteraturvidenskaben overfor, i at forstå toposet som et på én gang reelt sted og som litterær form, der overdrager os en måde at se og tænke et givent historisk rum.

\section{DEN DOBBELTE TOPIK}

Man kan i forlængelse heraf gøre en sidste, nu litteraturhistorisk, refleksion angående denne forståelse af topos'et som typisk realsted. Auerbach 
påpeger, hvordan "La cour et la ville" er et afgørende topos i midten af 1600-tallet. Men dette perspektiv kan udvides litteraturhistorisk, eftersom det jo ikke blot er under 1600-tallets absolutisme, at dette topos er centralt i fransk litteratur. Det er et topos som hele vejen frem til Den franske revolution anvendes til at fremskrive politiske, sociale og bymæssige spændinger. Og selv efter monarkiets fald forbliver det et centralt topos - vel i virkeligheden helt frem til Proust. Dets materielle, symbolske og imaginære komponenter ændrer sig naturligt nok over tid: med hoffets flytten frem og tilbage mellem Versailles og Louvre, med Den franske revolution, Napoleons modernisering af hoffet, restaurationsperioden, så Julimonarkiet og siden kejsertidens hof. Og samtidig hermed ændres dette topos i 1700-tallet med borgerskabets intellektualisering, dets nye salonkultur og gryende rettighedsfornemmelser; med Den franske revolution og senere med revolutionerne i 1830 og 1848, med Hausmanns Paris og borgerskabets "frigørelse" via kapitalisme og samtidige tvivl om standslegitimitet og anakronistiske stræben efter adelstitler. "Hoffet og byen" er således et helt afgørende topos i fransk litteratur, i stigende grad i romanen, mindre i teatret. Hvis dette topos oplagt er til stede i Montesquieu og Voltaire, i Laclos og Sade, så er det bemærkelsesværdigt, hvordan "la cour et la ville" stadig er operativt i 1900-tallets store franske roman. Tekster som f.eks. Balzacs Illusions perdues (Bristede forhåbninger), Stendhals Le Rouge et le noir (Rød og sort) og Flauberts L'Education sentimentale (Følelsernes opdragelse) er uforståelige uden den topiske spænding mellem "hof" og "by".

Hermed er vi på sporet af en helt afgørende funktion i det litterære topos, nemlig at det ikke alene er en repræsentationsform, men også, sådan som det også var udgangspunktet for Curtius, en traditionsdannende form. Toposet lever videre i den litterære form og tradition også hinsides den konkrete reference til et erfaringsmæssigt realrum, som var dets udgangspunkt. "La cour et la ville" er ikke længere en brændende politisk og social konfiguration af det erfarede rum for Balzac eller for Zola, som det var for Molières generation; men toposet er overleveret som en litterær refleksionsform, der, indenfor sine rammer, kan tematisere et sæt af nye historiske konflikter og affekter. Et godt eksempel herpå kunne være Balzacs Colonel Chabert (Oberst Chabert). Chabert var, takket være sine militære meritter, blevet adlet under Napoleon den 1. Under slaget ved Eylau spiller han en 
helterolle, men omkommer også - det tror i hvert fald både den parisiske offentlighed og hans nærmeste. Da han vender tilbage fra krigen efter 1815, er det imidlertid til et helt nyt regime, restaurationsperioden, hvor det nu er de gamle adelstitler og - slægter, som er nødvendige for social anerkendelse: Hans ejendom og goder er væk, hans kone har giftet sig igen og myndighederne vil ikke anerkende hans identitet. I Balzacs korte roman fremkalder og analyserer toposet "hof og by" således kronotopisk de følelsesmæssige og moralske konsekvenser af den politiske udvikling fra republik, over kejserdømme til restaurationstid.

Hvis vi, i forlængelse af denne litteraturhistoriske pointe om et givent topos' litteraturhistoriske efterliv, nu betænker nogle af de nye steder, f.eks. toget, restauranten eller klosteret, som den tidligt moderne og moderne litteratur fødtes sammen med, og som den udnyttede i sine fortællinger, kan kronotopens litteraturhistoriske status præciseres. Vi insisterede ovenfor på, at der til de nye steder hører et komplekst, men genkendeligt sæt af topisk konventionalitet (Auerbach talte om "typiske træk", Bakhtin om "assimilation"). Der er så at sige allerede etableret en tog-doxa eller en kloster-doxa for så vidt, at man på forhånd genkender og vil forstå, hvad f.eks. toget i Zolas roman La Bête humaine (Menneskedyret) implicerer af bevægelsesmuligheder og arbejdsforhold, teknologi og kapitalisme.

Denne fortrolighed med eller vilje til at se det historiske steds betydningslag som sandsynligt, dubleres imidlertid af, hvad man kan kalde, ikke litteraturens stilisering, men litteraturens re-topisering af realstederne. For samtidig med og oveni denne realstedernes doxa er det klart, at Zolas roman ikke kun søger at overbevise om togets realitet via præcise rejsetider for turen mellem Paris og Le Havre, via beskrivelser af togets mekaniske aspekter og via arbejderens opofrelse i forhold til både maskine og togkompagni. Denne realhistoriske doxa, som den kommer til udtryk i Zolas omhyggelige omgang med det nye steds materialitet, symbolik og imaginære, er fuldt overbevisende. Men samtidig hermed, og nu på det litteraturfunktionelle niveau, bruges toget til at fortælle en helt anden historie: Som litterært topos bruges toget og dets historisk prægnante stedslighed til at fortælle en historie om menneskeligt begær, om psykobiologisk ubalance, og ikke mindst om vold: Romanen tæller to voldtægter, adskillige mord, mindst to selvmord og diverse katastrofer. Den samme type argument kunne gø- 
res gældende i forhold til andre af de genkommende steder i litteraturen: fængsel, salon eller restaurant. Klosteret i litteraturen bliver heller ikke kun brugt til at vise, hvordan man forsager livets fristelser og lever et liv kendetegnet ved askese, cølibat, studier og bøn, men oftest til at beskrive frihedstrang, seksuelle eller psykologiske overgreb, hykleri osv. Restauranten bruges ikke kun til at dokumentere gastronomi, madpriser eller bordskik på et givet historisk tidspunkt men gerne det modsatte: pinlig opførsel, fuldskab, overdreven og dårlig smag. Litteraturen bruger på genkommende og konventionel vis steder med tilhørende materielle markører, symbol-økonomi og imaginære ressourcer, men ikke for at gentage deres historiske mening eller kulturelle funktion, men for at udforske og udvide eller for at kritisere denne mening og denne funktion. Stedet, toget f.eks., er en genkendelig form, som litteraturen ikke bare bruger til at gentage et genkendeligt konventionelt indhold, (f.eks. rejse, mekanik, geografi), men til at sige "noget andet", i Zolas tilfælde om menneskets dyriske natur. Udover den materielle, symbolske og imaginære prægnans, som giver disse steder genkendelighed, bruges de også til at fremskrive alle mulige andre forhold, som ikke nødvendigvis har noget med den realhistoriske doxa at gøre. Man kunne hævde, at man med denne dobbelte topik, realstedernes topik og den litterære topik har bragt sig i stand til at identificere både repetitionen af historisk genkendelige kontekster og litteraturens afvigende, udforskende og kritiske brug af disse historiske steder. Samtidig med at være funderet i ydre teknologiske, arkitektoniske, institutionelle og kulturelle faktorer er disse steder også funderet i visse brugsmønstre i de litterære traditioner. Og disse mønstre har deres egne litterære 'love', der synes at være formuleret på baggrund af, men også nærmest i modsætning til, stedernes (togets eller restaurantens) instrumentelle, kulturelle doxa. Det var formentlig en sådan generisk åbenhed Bakhtin bemærkede, da han konstaterede, at de fleste genrer kan knyttes til bestemte historiske kronotoper, og at bestemte genrer og undergenrer så at sige giver kronotopen et efterliv som en "kilde til at skabe billeder" (Bakhtin, "Forms of Time" 246) på senere stadier af genrens historie. Under alle omstændigheder er der et element af ikke-identitet mellem realsted og litterær brug heraf, således at realstedernes doxa kalder på litterær heterodoksi. Man kunne formulere det således, at stederne i litteraturen, i modsætning til realstederne, ofte har et moment af ikke-nødven- 
dighed, af kontingens i forhold til den forventede og normale brug af dem, f.eks. i den lange række af restaurantscener som i den litterære virkelighed ofte, og på genkommende vis, ikke handler om spisning men om kulturel kapital. Den konstante bevægelse fra realstedslig doxa til litteraturstedslig heterodoksi kunne man sammenfatte som "kontingenstopologi", altså som litteraturens artikulation af konventionelle steders sociale, psykologiske, politiske, kulturelle andethed. Om det er toget eller restauranten, klosteret eller retssalen, så synes der at være en tradition for i litteraturen at bruge disse steder med innovativt blik for at artikulere noget handlingsmæssigt eller tematisk uventet, overraskende eller tilfældigt og, kunne man sige, for konstant at poetisere det retoriske grundlag.

\section{SAMMENFATNING}

I rehabiliteringen af den litterære topologi forekommer forskellige metodiske og teoretiske operationer således frugtbare, hvis da ikke nødvendige. Det er i første omgang, som sagt, vigtigt at begribe stedets egenart ifølge dets historiske natur, samtidig med at man er opmærksom på, at et sted ikke bare er en geografisk eller topografisk lokalitet. Stedet rummer også en kronotopisk realitet, der sammenvæver materielle, imaginære og symbolske forhold i en konkret menneskelig livsverden. Udpegningen af et historisk prægnant sted indebærer således også, at man har blik for en række komplekse interaktioner mellem konkrete miljøer, adfærdsformer, magtforhold, tænkemåder og de menneskelige erfaringer, som heri overhovedet rammesættes. Det menneskelige rum er således karakteriseret ved på forhånd at være en social, historisk og antropologisk relationel realitet, og det er disse forhold, som gør det prægnant og udstyrer det med en typisk karakter. Man må imidlertid samtidig hermed, og her ligger forskellen vel mellem på den ene side den geografisk orienterede stedsteori og på den anden side rehabiliteringen af topologien, insistere på, at det prægnante rum lever videre i den litterære historie som særlig litterær form og dette uagtet forbindelsen til det realrum, som jo ellers var dets afsæt. Det var det, vi mente med den dobbelte topik, hvor et historisk bundet rum transformeres ind i en litterær tradition og lever videre i særlige genrer og trækker litteraturhistoriske linjer som refleksionsform, der kan 
tematisere nye historiske konflikter, nye sociale adfærdsformer og nye politiske situationer. Disse litterære topoi rummer en særlig logik for så vidt de, midt i al deres genkendelighed som historiske tog, restauranter eller klostre, synes at være interesserede $i$ at artikulere og fastholde nogle erfaringer, situationer og affekter, som ikke med nogen særlig nødvendighed er knyttet til disse steder: Man bruger restauranten til at tale om social kapital, toget til at tale om menneskeligt begær eller klosteret til at tale om hykleri og frihedsberøvelse. Den dobbelte topologi hentyder således til det forhold, at de rum som litteraturen bruger, på den ene side er genkendelige, sandsynlige og udstyret med en doxa, hvad angår deres materialitet, funktionalitet, symbolicitet og betydning. På den anden side refunktionaliserer litteraturen denne genkendelige form via alle mulige typer af handlinger, erfaringer og problemer, som ikke umiddelbart hører til her som del af realstedets genkendelighed, som del af dets doxa. På den måde kunne man tale om, at den litterære topologi ikke blot er funderet i konventionelle og genkendelige skemaer, men også rummer en egen eksperimenterende dimension, der bruger de fælles og almindelige rammer til sine uforudsete og udforskende refleksioner.

Carsten Meiner er professor, dr.phil. i fransk litteratur ved Københavns Universitet og har siden 2015 været leder forskningsprojektet "French Literary History: A Topology of Culture". Han er forfatter til Le Carosse Littéraire: L'invention du hazard (PUF, 2008) og har redigeret flere antologier.

Frederik Tygstrup er professor i Litteraturvidenskab på Institut for Kunst- og Kulturvidenskab, Københavns Universitet.

FROM NORMATIVE TO HISTORICAL TOPOS-RESEARCH

On the basis of Ernst Robert Curtius' topology, Mikhail Bachtine's theory of the chronotope, and Erich Auerbach's analysis of "la cour et la ville", this article envisions literary topology as the study of symbolic places in literary history. 


\section{KEYWORDS}

EN: Topos, chronotope, rhetoric, Ernst Robert Curtius, Mikhail Bakhtin

DA: Topos, kronotop, retorik, Ernst Robert Curtius, Mikhail Bakhtin

\section{LITTERATUR}

Amossy, Ruth og Herschberg Pierrot, Anne. Stéréotypes et clichés. Paris: Armand Colin, 1997.

Auerbach, Erich. Vier Untersuchungen zur Geschichte der Französischen Bildung. Bern: A. Francke AG Verlag, 1951.

Baeumer, Max L. "Vorwort". Toposforschung (red. Baeumer, Max L.). Wege der Forschung band CCCXCV, Darmstadt: Wissenschaftliche Buchgesellschaft, 1973.

Bakhtin, Mikhail. "Forms of Time and of the Chronotope in the Novel". The Dialogic Imagination (Red. Holquist). Austin, TX: University of Texas Press, 1981.

Curtius, Ernst Robert. "Beiträge zur Topik der mittellateinischen Literatur". Corona Querna, Festgabe Karl Strecker zum 80. Geburtstages dargebracht, Leipzig: Hiersemann, 1941.

Curtius, Ernst Robert. "Begriff einer historischen Topik". Zeitschrift für romanische Philologie, 58 (1938): 129-142.

Curtius, Ernst Robert. Europäische Literatur und lateinisches Mittelalter. Bern: Francke Verlag, 1948.

Lefebvre, Henri. La Production de l'espace. Paris: Anthropus, 1974.

Obermayer, August. "Zum Toposbegriff der modernen Literaturwissenschaft". Toposforschung (red. Baeumer, Max L.). Wege der Forschung band CCCXCV, Darmstadt: Wissenschaftliche Buchgesellschaft, 1973.

Perelman, Chaim. L'Empire rhétorique. Rhétorique et argumentation. Paris: Vrin, 1997.

Reboul, Olivier. Introduction à la rhétorique. Paris: PUF, 1991. 
54 KULTUR \& KLASSE * $123 * 2017$ TOPOLOGI 